\title{
Ebola and other viral haemorrhagic fevers
}

\author{
Be prepared, with new guidance featuring old and well established principles
}

\author{
Tom E Fletcher Wellcome trust training fellow ${ }^{1}$, Timothy J G Brooks clinical services director ${ }^{2}$, \\ Nicholas $\mathrm{J}$ Beeching senior lecturer (clinical) in infectious diseases ${ }^{1}$
}

${ }^{1}$ Liverpool School of Tropical Medicine, Liverpool L3 5QA, UK; ${ }^{2}$ Rare and Imported Pathogens Laboratory, Public Health England, Porton Down, Salisbury, UK

The ongoing Ebola outbreak in West Africa is the largest and most complicated that the world has even seen. Since it was first identified in the forested regions of south eastern Guinea in March, ${ }^{1}$ it has spread to Liberia, Sierra Leone, and Nigeria and has now been declared a "public health emergency of international concern" by the World Health Organization. ${ }^{2}$

Ebola virus is one of a group of zoonotic viruses that can cause severe disease in humans.-5 Viruses that cause viral haemorrhagic fever include Lassa virus, Crimean-Congo haemorrhagic fever virus, Marburg virus, and emerging ones such as Lujo virus. These viruses are of particular public health importance because of their ability to spread to carers and healthcare workers, the often high case fatality rate, difficulties in their rapid recognition, and the lack of effective specific treatments. ${ }^{3-6}$

The current epidemic is caused by the Zaire strain of Ebola virus, which has a mortality of 50-90\% in endemic settings. No licensed cure or vaccine is available, although research is in progress to develop these and two American healthcare workers are reported to have received an experimental monoclonal antibody preparation after acquiring Ebola virus infection in Liberia. ${ }^{7}$ The keys to case management are early recognition and isolation of cases, use of personal protective equipment, and the provision of supportive medical care to reduce mortality. $^{26}$

Guidance on management of viral haemorrhagic fever was developed for UK healthcare professionals after a laboratory acquired case of Ebola infection, ${ }^{8}$ and the first cases of Lassa fever imported to the United Kingdom in the 1970s. The guidance was revised by the Advisory Committee on Dangerous Pathogens in 2012 and updated last month. ${ }^{9}{ }^{10}$ Similar guidelines are available in the United States ${ }^{4}$ and European countries, ${ }^{11}$ and they differ in emphasis from those developed for use in resource poor settings. ${ }^{6}$ Guidance and information for the British public are also available in a range of reliable internet resources including NHS Choices. ${ }^{12-14}$

Imported cases of viral haemorrhagic fever in the UK are rare and patients are often healthcare workers, military personnel, or others who work in rural environments..$^{15}$ These diseases differ from infections such as influenza or severe acute respiratory syndrome because they are usually transmitted by direct contact with blood or other body secretions rather than being airborne. Also, patients with viral haemorrhagic fever are not infectious until they develop symptoms. The likelihood of epidemic transmission in Western settings, including to fellow travellers on airplanes, is therefore low.

The initial clinical presentation is non-specific, so viral haemorrhagic fever should be considered in any patient with a fever or history of fever in the previous 24 hours who has returned from an endemic area in the past 21 days (the longest incubation period). Most febrile travellers returning from endemic areas will have other infections, such as malaria, which also need rapid diagnosis and management. ${ }^{16}$ Unfortunately, a travel history is rarely elicited in most day to day consultations, leading to delays in diagnosis and in the isolation of patients at risk. $^{17-19}$

The updated guidance is aimed at a range of clinicians, both specialist and non-specialist. It includes flow diagrams, tables, and technical appendices that offer clear advice on the assessment of exposure risk, management of patients, and all aspects of infection control. It links to the UK's Imported Fever Service, ${ }^{20}$ which can provide case specific advice on risk assessment and rapid diagnostic testing to augment advice from local infection specialists.

The guidance recommends that patients initially identified as having a possible viral haemorrhagic fever should be isolated until the results of specific investigations are obtained from reference laboratories, which may take up to 24 hours. It is important not to delay diagnosis and treatment of more common diseases, such as malaria or typhoid, during this period. In the past this has been a problem outside specialist centres, ${ }^{21}$ owing to safety concerns associated with performing otherwise routine blood tests in patients with a suspected viral haemorrhagic fever. The updated guidance is welcome because it acknowledges that it is safe to perform these tests locally to support clinical 
management while awaiting the results of specific diagnostic tests.

To be fully effective the new guidance must be supported by the training of medical, nursing, and laboratory staff in risk assessment, universal precautions, and the use of personal protective equipment. Follow-up of contacts of cases is essential for infection containment. In the event that a patient tests positive, specialist care is available in the UK through the high level isolation unit, based at the Royal Free Hospital in London. The unit can provide advice on safe care for high risk patients and safe transfer, as well as taking over the management of seriously ill patients in the tailor made facility. The UK has specially equipped ambulances and trained staff to accomplish such transfers when needed.

In summary, the risk of a traveller acquiring a viral haemorrhagic fever and importing it to the UK is very small but must be considered. The key message for healthcare professionals is to take a travel history from all patients with fever and perform a more specific risk assessment for patients returning from areas endemic for these diseases, according to the recently updated guidance. All frontline hospital doctors and managers also make sure they can answer "yes" to the following questions: have you considered that someone with viral haemorrhagic fever could present to your facility? Do you have a local protocol? If so, can you and your staff find it? And, lastly, have you adequately trained your staff in the use of personal protective equipment? If not, now is the time to do so.

Funding: TF is supported by a Wellcome Trust research fellowship and by the Army Medical Directorate. TJGB and NJB receive support from the National Institute for Health Research health protection research unit in emerging and zoonotic infections, which is a collaboration between the University of Liverpool, the Liverpool School of Tropical Medicine, and Public Health England. The views expressed are those of the authors and not necessarily those of the NHS, the National Institute for Health Research, the Ministry of Defence, the Department of Health, or Public Health England.

Competing interests: We have read and understood BMJ policy on declaration of interests and declare the following interests: TJGB is director of the Rare and Imported Pathogens Laboratory, which provides the national laboratory services for diagnosis of viral haemorrhagic fever. TJGB and NJB are leads for the national Imported Fever Service (IFS), which is an integral part of the current algorithms for management of viral haemorrhagic fever in the UK. The IFS is supported by Public Health England and the NHS (Royal Liverpool and Broadgreen University hospitals and UCLH hospital trusts.
Provenance and peer review: Commissioned; not externally peer reviewed.

1 Baize S, Pannetier D, Oestereich L, Rieger T, Koivogui L, Magassouba N'F, et al. Emergence of Zaire Ebola Virus disease in Guinea-preliminary report. N Engl J Med 2014; published online 16 April; doi:10.1056/NEJMoa1404505.

2 WHO. WHO statement on the meeting of the International Health Regulations Emergency Committee regarding the 2014 Ebola outbreak in West Africa. 2014. www.who.int/ mediacentre/news/statements/2014/ebola-20140808/en/.

3 Public Health England. Viral haemorrhagic fever. www.hpa.org.uk/Topics/ InfectiousDiseases/InfectionsAZ/ViralHaemorrhagicFever.

4 Centers for Communicable Disease Control and Prevention. Ebola hemorrhagic fever. www.cdc.gov/vhf/ebola/index.html.

5 WHO. Haemorrhagic fevers, viral. www.who.int/topics/haemorrhagic_fevers_viral/en/.

6 WHO. Clinical management of patients with viral haemorrhagic fever: a pocket guide for the front-line health worker. 2014. www.medbox.org/preview/53b3a4e3-4bd0-41d2-a808$61471 \mathrm{fcc} 7 \mathrm{~b} 89 / \mathrm{doc} . \mathrm{pdf}$

7 Centers for Communicable Disease Control and Prevention. Questions and answers on experimental treatments and vaccines for Ebola. www.cdc.gov/vht/ebola/outbreaks/guinea/ qa-experimental-treatments.html.

8 Emond RT, Evans B, Bowen ETW, Lloyd G. A case of Ebola virus infection. BMJ 1977;2:541-4.

9 Advisory Committee on Dangerous Pathogens. Management of hazard group 4 viral haemorrhagic fevers and similar human infectious diseases of high consequence. Department of Health, 2012. www.hpa.org.uk/webc/HPAwebFile/HPAweb_C/ 1194947382005

10 Advisory Committee on Dangerous Pathogens. Viral haemorrhagic fever risk assessment Version 2.Department of Health, 2014. www.hpa.org.uk/webc/HPAwebFile/HPAweb_C/ 1317135155050.

11 Belgian Superior Health Council. Practical recommendations to the attention of healthcare professionals and health authorities regarding the identification of and care delivered to suspected or confirmed carriers of highly contagious viruses (of the Ebola or Marburg type) in the context of an epidemic outbreak in West Africa. 2014; Publication 9188; www. abihh.be/pdf2/ebola.pdf.

12 UK Government. Ebola: government response. 2014. www.gov.uk/government/news/ ebola-government-response.

13 NHS Choices. Ebola virus disease. www.nhs.uk/conditions/ebola-virus/Pages/Ebola-virus. aspx.

14 National Travel Health Network and Centre. www.nathnac.org/travel/news/ebola westafrica 220714.htm.

15 Beeching NJ, Fletcher TE, Hill DR, Thomson GL. Travellers and viral haemorrhagic fevers: what are the risks? Int J Antimicrob Agents 2010;36:S26-35.

16 Johnston V, Stockley JM, Dockrell D, Warrell D, Bailey R, Pasvol G, et al. Fever in returned travellers presenting in the United Kingdom: recommendations for investigation and initial management. J Infect 2009;59:1-18.

17 Price VA, Smith RA, Douthwaite S, Thomas S, Almond DS, Miller ARO, et al. General physicians do not take adequate travel histories. J Travel Med 2011;18:271-4.

18 Anathallee M, Curphey A, Beeching N, Carley S, Crawford I, Mackway-Jones K. Emergency departments (EDs) in the United Kingdom (UK) are not prepared for emerging biological threats and bioterrorism. $J$ Infect 2007;54:12-7.

19 Fusco FM, Schilling S, De laco G, Brodt HR, Brouqui P, Maltezou HC, et al. Infection control management of patients with suspected highly infectious diseases in emergency departments: data from a survey in 41 facilities in 14 European countries. BMC Infect Dis 2012;12:27.

20 Public Health England. Imported Fever Service. www.hpa.org.uk/ProductsServices/ MicrobiologyPathology/LaboratoriesAndReferenceFacilities/ RareAndlmportedPathogensDepartment/ImportedFeverService.

21 Woodrow CJ, Eziefula AC, Agranoff D, Scott GM, Watson J, Chiodini PL, et al. Early risk assessment for viral haemorrhagic fever: experience at the Hospital for Tropical Diseases, London, UK. J Infect 2007;54:6-11.

Cite this as: BMJ 2014;349:g5079

(c) BMJ Publishing Group Ltd 2014 